\title{
Vocational awareness and aspiration of seafaring students in Taiwan
}

\author{
Chun Pong Wong \\ Department of Shipping Technology, \\ National Kaohsiung University of Science and Technology, Kaohsiung, Taiwan
}

\begin{abstract}
Purpose - This study aims to examine variables and factors in vocational awareness and attitudes that affect the vocational aspiration of seafaring course students who are potential future seafaring employees.

Design/methodology/approach - A literature review was conducted to identify factors that prompt students in seafaring courses to pursue seafaring careers, followed by a design of preliminary questionnaire questions to survey students' perception on the conditions of seafaring careers (i.e. vocational awareness) and their intention to pursue a seafaring career (i.e., vocational aspiration). A total of 744 seafaring course students in four Taiwanese universities completed a questionnaire developed according to the previous studies. A structured equation modelling was conducted in this research including model validity, goodness of fit, model correction and mediation effects.

Findings - With a model consisting of four factors for vocational awareness, three factors for overall attitudes and vocational aspiration as a dependent variable, the results showed that factors of vocational awareness and students' overall attitudes were significantly correlated, and the factors of overall attitudes exhibit strong mediation effects on vocational aspiration from vocational awareness. The results confirmed that the factors are important determinants for the vocational aspiration of students.

Originality/value - The findings of this study provide a comprehensive approach to understand students' seafaring aspiration for the universities, governments and shipping companies. Seafaring policies and management are discussed from the research findings.
\end{abstract}

Keywords Attitudes, Seafaring careers, Shipping navigation, Vocational aspiration,

Vocational awareness

Paper type Research paper

\section{Introduction}

Taiwan is an island country with robust manufacturing industries that rely on shipping for cargo transportation. To support the shipping corporations in the country, there are many seafaring courses in vocational schools and universities who churn out qualified graduates to meet the needs of the industry (Ocean Affairs Council, 2006; Wong, 2010, 2012).

In the 20th century, there were no difficulties for the industry to recruit qualified navigation officers and engineers to work and live on ships with social isolation for the contract periods, because seafaring jobs commanded better remunerations and conditions than non-seafaring jobs. Since the turn of the millennium, however, the remuneration gaps between seafaring and non-seafaring jobs have narrowed while the sea conditions, threats of pirates, etc., have

(C) Pacific Star Group Education Foundation. Licensed re-use rights only

The author would like to thank the Chief Editor, Prof. Chin-Shan Lu and the anonymous reviewers for their constructive comments and suggestions, and Mr. Chong-Ming $\mathrm{Lu}$ for his support and assistance.
Vocational awareness and aspiration

Received 31 December 2019 Revised 19 August 2020 21 September 2020

14 December 2020 27 April 2021 Accepted 28 April 2021

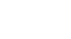


MABR

7,2

deteriorated, hampering more students in seafaring courses to pursue careers in the industry (Tsai and Liou, 2017; Westlander, 1994). Seafarers face regularly changing conditions and challenges, while staying away from families and friends for prolonged periods (Carotenuto et al., 2012; Parkes et al., 2005; Slišković and Penezić, 2015b). Besides, it takes years of studies and work to gain the experience, knowledge, skills, qualification and better remuneration and ranks, all the time bearing the high risks of working on ships and international waters. No wonder, recent data show that a percentage of graduates from the seafaring courses do not pursue seafaring careers (Tsai and Liou, 2017).

Through education systems, governments and educators aim to cultivate students with relevant and sufficient skills and prepare them for the future job markets, to support the industries and the economy. The goal of education is achieved when any students who complete all course requirements satisfactorily and pursue seafaring as careers. Therefore, the governments and the education establishments must adopt the right mix of practices to attract potential students to consider seafaring as a career before applying for the relevant courses.

Thus, the targets of the study are students in universities of marine technology who are studying for qualifications to work on commercial ships in the roles of navigation or engineer officers. It addresses the questions: 1 ) whether strengthening vocational awareness can reinforce vocational aspiration for more students to pursue seafaring careers? and 2) what factors influence vocational aspiration? (Ocean Affairs Council, 2006). With the results and variables and factors identified, it recommends that the government improves on the conditions of the seafaring jobs, and that the vocational educators improve practices in teaching and recruitments of new students in seafaring courses.

Vocational awareness refers to the understanding of the reasons, values, rewards, requirements, processes, etc., of a future career (Cherry and Gear,1987; Ferrara et al., 1985; Hyland, 2019; Jonathan, 1998; Yu et al., 2010; Supper,1981, 1990, 1994). Overall attitudes can be defined as a way of feeling, a manner of acting, personal perceptions towards a career. This term covers personal preferences or judgments such as good-bad, harmful-beneficial, pleasantunpleasant, likable-unbearable, etc., and interests (i.e. career ambitions), motivation, etc., towards a future career (Ajzen, 2001; Hidi and Renninger, 2006; Pintrich and Schunk, 2002; Ryan and Deci, 2000; Deci et al., 1991). Vocational aspiration can be defined as a plan and willingness to pursue a career (Ajzen, 1991; Burman, 2016; Sheldrake et al., 2017; Super, 1963, 1981, 1990).

\section{Literature review}

\subsection{Factors for vocational awareness}

While different terminology and methodology are used in the referenced literature for vocational decisions, five common factors are identified as listed in Table 1: competence (knowledge and skills), job security (work requirements), rewards and benefits (RB) (remuneration), environment and conditions (EC) (work environments) and social influences (SI) (external influences). Vocational awareness is a precursor for career counselling and development that influences career choices deeply (Cherry and Gear, 1987; Ferrara et al., 1985; Hyland, 2019; Jonathan, 1998; Yu et al., 2010). Separately, Super (1981, 1990, 1994) proposed that vocational awareness refers to subjective concepts on work requirements, rewards, environment and trends related to the chosen career. To make a decision on a future vocation, a person must consider many factors, including knowledge and skills, work requirements, RB, work environment and SI (Ford and Lerner, 1992; McGroarty, 1985; Mudhovozi and Chireshe, 2012; Slišković and Juranko, 2019; Spokane and Cruza-Guet, 2005; Tuan et al., 2005). In addition, the awareness on (knowing) one's own capabilities and expectation is essential for a successful career (Lent et al., 1994; Herr and Cramer, 1988; Holland, 1985; Yu et al., 2010; Wise et al., 1976). 


\begin{tabular}{|c|c|c|c|}
\hline Scholars & Arguments of the factor & Summarize factor & Vocational \\
\hline Wise et al. (1976) & Knowledge, self-concepts & \multirow[t]{10}{*}{ Competence } & aspiratior \\
\hline Super $(1981,1990,1994)$ & Knowhow & & \\
\hline Helwig (1984) & Previous work experience & & \\
\hline Wu and Lou (2010) & Work ability and work ethics & & \\
\hline Cherry and Gear (1987) & Reading ability & & \\
\hline McGroarty (1985) & Career ability & & 129 \\
\hline Ferrara et al. (1985) & Vocational knowledge & & \\
\hline Holland (1985) & Vocational knowledge & & \\
\hline Baartman (2018) & $\begin{array}{l}\text { Knowledge as per the engage work } \\
\text { needs }\end{array}$ & & \\
\hline Broad (2016) & Explicit and tacit knowledge & & \\
\hline Holland (1985) & Vocational information & \multirow[t]{5}{*}{ Job security } & \\
\hline Helwig (1984) & Steady and aptitudes of the job & & \\
\hline Cherry and Gear (1987) & Social and economic factors & & \\
\hline Slišković and Penezić (2015b) & $\begin{array}{l}\text { Nature and dynamic of job, changes } \\
\text { in maritime sector }\end{array}$ & & \\
\hline Westlander (1994) & $\begin{array}{l}\text { Relatively rapid changes in the } \\
\text { economic system }\end{array}$ & & \\
\hline Wise et al. (1976) & Value & \multirow[t]{5}{*}{ Rewards and benefits } & \\
\hline Helwig (1984) & Financial needs & & \\
\hline Wu and Lou (2010) & Economic Factors, work welfare & & \\
\hline Tuan et al. (2005) & Science learning value & & \\
\hline $\begin{array}{l}\text { Slišković and Penezić (2015b) and } \\
\text { Slišković and Juranko (2019) }\end{array}$ & Financial stability and security & & \\
\hline Super $(1981,1990,1994)$ & $\begin{array}{l}\text { knowledge on vocational } \\
\text { environment }\end{array}$ & \multirow[t]{5}{*}{ Job environment and conditions } & \\
\hline Helwig (1984) & $\begin{array}{l}\text { Friendliness of co-worker, } \\
\text { transportation available }\end{array}$ & & \\
\hline Cherry and Gear (1987) & Career interventions & & \\
\hline Slišković and Penezić (2015b) & $\begin{array}{l}\text { Ratio between working and } \\
\text { vacation days, and quality of days } \\
\text { off, risk at sea }\end{array}$ & & \\
\hline Carotenuto et al. (2012) & $\begin{array}{l}\text { loneliness on board, fatigue, multi- } \\
\text { nationality, limited recreation } \\
\text { activity, sleep deprivation }\end{array}$ & & \\
\hline Helwig (1984) & Family's wishes & \multirow[t]{13}{*}{ Social influences } & \\
\hline Wu and Lou (2010) & Opinions of others & & \\
\hline Cherry and Gear (1987) & Features of the school & & \\
\hline Ford and Lerner (1992) & $\begin{array}{l}\text { Transactions with their } \\
\text { environment }\end{array}$ & & \\
\hline Holland (1997) & Environmental interaction and & & \\
\hline Spokane and Cruza-Guet (2005) & environmental characteristics & & \\
\hline Tuan et al. (2005) & & & \\
\hline Baartman (2018) & On-campus learning environment & & \\
\hline Broad (2016) & Transfer from career to classroom & & \\
\hline Shumba and Naong (2012) & Influence of family and teachers & & \\
\hline Mudhovozi and Chireshe (2012) & $\begin{array}{l}\text { Influence of parents, teachers and } \\
\text { friends }\end{array}$ & & Table 1. \\
\hline Carotenuto et al. (2012) & Separation from family & & Factors of vocational \\
\hline Jonathan (1998) & Environmental impacts & & awarenes \\
\hline
\end{tabular}


MABR

7,2

In a study on vocational awareness scale and career decisions conducted by high school students, Helwig (1984) proposed that the factors, in the order of importance level, are: job stability and security, vocational interests (preferences for certain tasks or activities), financial rewards, aptitudes (the capacity to do or learn something), friendliness of coworkers, transportation availability, previous work experience and family's influences. A study on predictability of vocational awareness for career decisions by students in child care courses ranks the key influencing factors (i.e. predictors) as: personal circumstances, personal capability and ethics, monetary rewards, work benefits and opinion of others (Wu and Lou, 2010).

Baartman (2018) studied how vocational students learn various types of knowledge from school-based and workplace-based learning environments and concluded that these two types of learning are complementary to each other. Broad (2016) proposed that vocational decisions are influenced by competence and SI. Competence refers to knowledge (declarative facts; explicit knowledge) and skills (procedural ability; tacit knowledge), and SI refers to the status of the intended vocation, as regarded by individuals or the society as a whole.

Slišković and Penezić (2015b) conducted a survey on career decisions of seafarers and identified the following positive factors: financial stability and security, ratio between working and vacation days, quality of days off and nature and dynamics of jobs. The negative factors include: separation from families, limited promotion opportunities, changes in seafaring jobs and danger and risks of shipping navigation. Shumba and Naong (2012) propose that for their career choices, medical students were influenced by factors including the family, self-efficacy, teachers and interest.

Based on the theories and propositions of reviewed literatures regarding the factors of vocational decisions, Table 1 lists four factors for vocational awareness: competence and job security (CS), RB, EC and SI. The literatures reviewed are categorized against vocational awareness factors as listed in Table 1.

\subsection{Theories on overall attitudes}

Ajzen (2001) surveyed academic papers and books on the subjects of Attitude constructs for students in the social and behavioural sciences courses, and stated: "According to the theory of planned behaviour, people act in accordance with their intentions and perceptions of control over the behaviour, while intentions in turn are influenced by Attitudes towards the behaviour, subjective norms, and perceptions of behavioural control". The term Interest refers to the relationship between a person and things. Hidi and Renninger (2006) defined Interest as: "the psychological state of engaging or the predisposition to reengage with particular classes of objects, events, or ideas over time." Furthermore, interest can be divided into short-term situational interest (state) and long-term personal interest (disposition).

Motivation is "about what gets an individual moving (energization) towards what activities or tasks (direction)" (Pintrich and Schunk, 2002). A leading theory in this field is the self-determination theory (SDT) proposed by Ryan and Deci (2000), which proposes that the basic psychological needs for competence, autonomy and relevance are the ultimate drivers of behavioural choices. People tend to behave in ways to satisfy these needs and avoid behaviours that threaten the fulfilment of these needs (failure avoidance). SDT offers a developmental perspective: motivation can be both externally driven or developed autonomously and leads to activities that successfully contribute (competence) towards selfselected (autonomy) and meaningful (relevance) goals. Furthermore, SDT proposes a continuum from pure externally driven behaviour (avoid punishment) to autonomous internally driven behaviour (intrinsic motivation). 
Deci et al. (1991) published the self-determination perspective theory, which proposes that attributes that contribute to better results in education are an interest in learning, a valuing of education and a confidence in one's own capacities. Separately, Osborne et al. (2003) proposed that classroom environment and activities provide important influences for students to become interested in scientific topics. Tsai and Liou (2017) researched recruitment management for seafarers and concluded that factors that influence work performance of seafarers include work attitude, welfare and opportunity, loyalty and salaries.

Boxer et al. (2011) studied factors affecting performance of students and found that students whose performance is worse than expected show signs of test/performance anxiety and elevated behavioural/emotional difficulties. Savelsbergh et al. (2016) designed a multi-layered framework to study factors that influence attitudes and achievement of students in science and mathematics classes. The findings show that the influencing factors include relevance, interest, self-efficacy and subjective norm/ normality (of scientists). Furthermore, relevance is divided into personal relevance and societal relevance, and interest is divided into classroom interest, leisure interest and career interest.

Some research papers on influencing factors in the fields of education, psychology, management, etc., have been referenced: motivation (Enache and Matei, 2017; Potvin and Hasni, 2014; Schommer, 1990; Tuan et al., 2005; Virtanen et al., 2014; Watt and Richardson, 2007, 2012); interest (Potvin and Hasni, 2014); relevance (Kind et al., 2007; Potvin and Hasni, 2014; Schommer, 1990; Tuan et al., 2005; Watt and Richardson, 2007, 2012); confidence (Bassot, 2019; Kind et al., 2007; Schommer, 1990); self-efficacy (Bassot, 2019; Tuan et al., 2005; Virtanen et al., 2014); and anxiety (Bussing, 1999; Hong, 2010). These factors are grouped as overall attitudes for the quantitative research towards vocational awareness and vocational aspiration, as shown in Table 2.

\subsection{Theories on the study model towards vocational aspiration}

The factors that university students consider while choosing future vocations include work conditions, general attractiveness of the occupation, income and compensation, personal prospects or general relevance, long-term potential and job security, consistency with personal talent, education or ability, the type and nature of colleagues, prospects of maintaining long-term interest, opinion of friends and family, altruistic concerns and ethical considerations (Galotti and Kozberg, 1987; Burman, 2016). Sheldrake et al. (2017) studied career aspirations of students in science courses and concluded: "Developing students' attitudes, and hence their aspirations, through highlighting the applications and relevance of science to everyday life may be beneficial."

The career self-concept proposed by Super (1963, 1981, 1990) include subjective perceptions and personal attributes relevant to the chosen occupations. Besides, these personal attributes (properties) include individual interests, capabilities, personal traits and values. This is to say that one's attitudes affect the decisions on future careers. Ajzen (1991) developed the theory of planned behaviour and proposed that behaviour is deliberative and planned. Intention is cognitive expressions of an individual's willingness to execute specific behaviours, and they are the immediate antecedents of behaviours. Furthermore, there are three factors that determine intentions: attitude towards the behaviour, subjective norms and perceived behavioural control. In other words, both vocational awareness and overall attitudes should have positive influences over aspiration to pursue a career (vocational aspiration). 


\section{MABR}

7,2

Scholars Arguments of the factor

Summarize factor

Potvin and Hasni (2014)

Savelsbergh et al. (2016)

Schommer (1990)

Enache and Matei (2017)

\section{2}

Tuan et al. (2005)

Virtanen et al. (2014)

Watt and Richardson $(2007,2012)$

Tsai and Liou (2017)

Potvin and Hasni (2014)

Savelsbergh et al. (2016)

Deci et al. (1991)

Osborne (2003)

Potvin and Hasni (2014)

Savelsbergh et al. (2016)

Schommer (1990)

Kind et al. (2007)

Tuan et al. (2005)

Watt and Richardson $(2007,2012)$

Tsai and Liou (2017)

Schommer (1990)

Kind et al. (2007)

Deci et al. (1991)

Bassot (2019)

Savelsbergh et al. (2016)

Tuan et al. (2005)

Virtanen et al. (2014)

Bassot (2019)

Table 2.

Schommer (1990)

Factors of overall

Boxer et al. (2011)

attitudes

Hong (2010)

Bussing (1999)

Motivation

Motivation

Subjective norm/normality of scientists

Mathematics learning motivation

Motivations

Achievement goal

Motivation

Motivations

Environmental motivation

Interest

Interest

Interest in learning

Interest towards science

Relevance

Relevance

Mathematics relevance

Importance of science, practical work in science

Performance goal

Teaching engagement

Welfare and opportunity

Mathematics learning confidence Confidence

Self-concept in science

Confidence in their own capacities

Confidence

Self-efficacy

Self-efficacy

Self-efficacy

Self-efficacy

Mathematics anxiety

Test/performance anxiety

Learning anxiety

Stress

\section{Methodology}

3.1 Research framework and hypotheses

To study vocational awareness and attitudes of students in shipping navigation courses, and to identify factors (variables) related to vocational aspiration of the students, the following steps were taken:

- investigate factors for vocational awareness and overall attitudes regarding seafaring careers;

- design a questionnaire to survey the students' tendencies to pursue seafaring careers (vocational aspiration);

- analyse the correlation among vocational awareness, overall attitudes and vocational aspiration;

- analyse any mediation effect among vocational awareness, overall attitudes and vocational aspiration; and

- analyse the data model and identify key factors influencing the predicative power of factors of vocational awareness and overall attitudes on vocational aspiration. 
As per the theories and concepts of the reviewed literature, Figure 1 proposes a model of vocational aspiration to show the relationship among vocational awareness, overall attitudes and vocational aspiration. The dotted line between vocational awareness and vocational aspiration indicates that this correlation is subject to a mediation test.

Based on the research goals and findings from the literature review, the following hypotheses were proposed:

H1. Students' vocational awareness positively affects their overall attitudes of seafaring.

H2. Students' overall attitudes positively affect their vocational aspiration in seafaring.

H3. Students' vocational awareness positively affects their vocational aspiration in seafaring.

H4. Students' overall attitudes play a mediating effect in the relationships between vocational awareness and vocational aspiration.

\subsection{Questionnaire design and data collection}

Adopting quantitative empirical methods to conduct this study, the study starts with the review of relevant literature to identify theories over vocational awareness, overall attitudes and vocational aspirations. The results were used to compile a preliminary questionnaire with seven-point Likert scales for each question.

Following a preliminary survey, the returned samples were analysed through a process of item analysis, reliability assessment and principal factor analysis, using SPSS Version 18, AMOS Version 26 and STATABLE. The formal questionnaire (Appendix) was produced following the removal of invalid questions and minor modifications.

\subsection{Analytical method}

This study adopts a structural equation modelling (SEM) technique to process multiple dependent variables simultaneously, estimate potential factors of multi-index measuring systems, enable dependent and independent variables to include measurement errors and to estimate the fitness of the overall models.

By contrast, conventional general regression analyses, such as those using SPSS software, involve mean estimates which contain errors therefore affecting the accuracy of the construct reliability tests and the validity of the factorial structures (Bollen and Long, 1993). Furthermore, SEM can better handle second-ordered constructs with two-stage complex models similar to the model for vocational aspiration adopted in this study.

\section{Results of analyses}

A total of 1,176 formal questionnaires were distributed to students in four Taiwanese universities that have seafaring courses. Except for 166 students who were taking

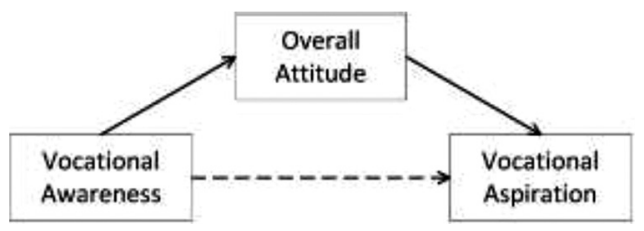

Figure 1. Model of vocational aspiration 
MABR

7,2

internship training on ships, the students in 29 classes were requested by the teachers or instructors to fill in the questionnaires during class time from April 2020 to July 2020. There was a total of 896 questionnaires returned; out of these, 122 were disqualified resulting in 774 valid returns (i.e. a $65.8 \%$ valid rate, well above the required 150 samples or 10-15 times the number of variables for meaningful SEM analysis). The valid samples were processed on IBM's SPSS AMOS software v.26.0 to verify that the constructs are valid and reasonable, model fit indices are acceptable and a mediation effect can be established among the three latent variables: vocational awareness (VAwa), overall attitudes (OAtt) and vocational aspiration (VAsp).

\subsection{Confirmatory factor analysis for model validity and goodness of fit}

The model of vocational aspiration (Figure 1) contains three second-order latent variables: VAwa, OAtt and VAsp. Among these variables, VAwa has four first-order factors (i.e. manifest variables): CS, RB, SI and EC; OAtt has three first-order factors: motivation and interest and relevance (MIR), confidence and self-efficacy (CSE) and anxiety (ANX); and VAsp has no first-order variables. The sample data were analysed using two-step modelling CFA methods on AMOS software, including model estimation, validity assessment, application of modification index and model trimming of items that show dependent errors. Table 3 shows the results of the analyses.

The columns of model estimates show values: regression weights (estimates), standard error of estimate, critical ratio ( $t$-values) and $P$ (significance of correlations). The $P$ column shows three asterisks for all of the variable, indicating that for each variable, the probability that a null hypothesis being true is less than 0.001 , therefore the alternative hypothesis (that the variable is significant in the model) is most likely ( $>99.9 \%$ ) true.

The convergent validity method verifies the validity of each factor in the model. The columns list standardized regression weights, squared multiple correction, composite reliability $(\mathrm{CR}$, which should be $>0.7)$ and average of variance extracted (AVE, which should be $>0.5$ ) (Fornell and Larcker, 1981). The model fit indices columns list the indices of model fit, including $X^{2}$ (chi-square), degree of freedom (df), $\chi^{2} / \mathrm{df}$ (normed chi-square), goodness of fit (GFI), adjusted GFI (AGFI) and root mean square error of approximation (RMSEA) which should be $<0.08$ for the model to be assessed as having an acceptable good fit with the sample data.

For the first-order factor of ANX, the CR value in the convergent validity study was 0.602 $(<0.7)$, and the AVE value was $0.340(<0.5)$. Besides, the value of $\chi^{2} / \mathrm{df}$ for the factor MIR was 6.39 which is slightly outside of the preferred range $(<5)$. Considering the support of literature and the significance of ANX and MIR over vocational choices, it was decided to keep these factors for the study. Apart from these two first-order factors, the values for the other first- and second-order factors all fall within the ranges of good model fit, indicating that the constructs of VAwa, VAtt and VAsp are within the guidelines and requirements of confirmatory factor analyses.

\subsection{Structural equation modelling analysis results}

The values produced through these tests are mostly within the ranges specified for the SEM analyses. However, in the multivariate normality test, one variable came up with a skew value $>1$, seven variables that came to have kurtosis values $>7$ and a multivariate critical ratio value reached 118.196, much greater than the theoretical CR $<5$ (Kline, 2011). As these values do not match the normality of multivariate analysis and may cause errors relating to under-estimated parameters or chi-square values, a bootstrap method was adopted to modify the indices. 

aspiration

Table 3. CFA results of model estimates, convergent validity and model fit indices 


\begin{tabular}{l} 
MABR \\
7,2 \\
136 \\
\hline
\end{tabular}

$\mid$

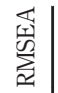

空

(1)

氧

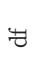

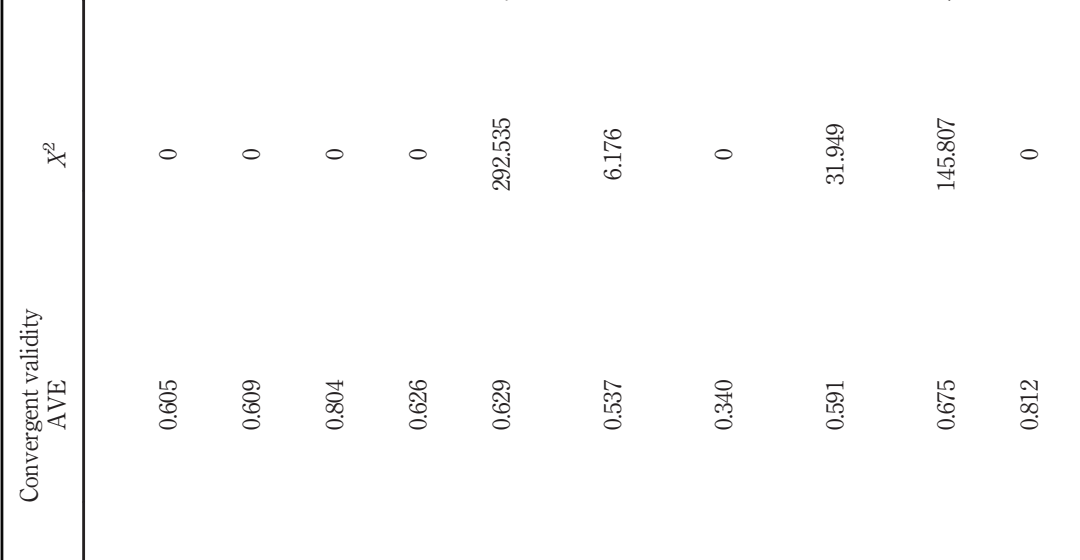

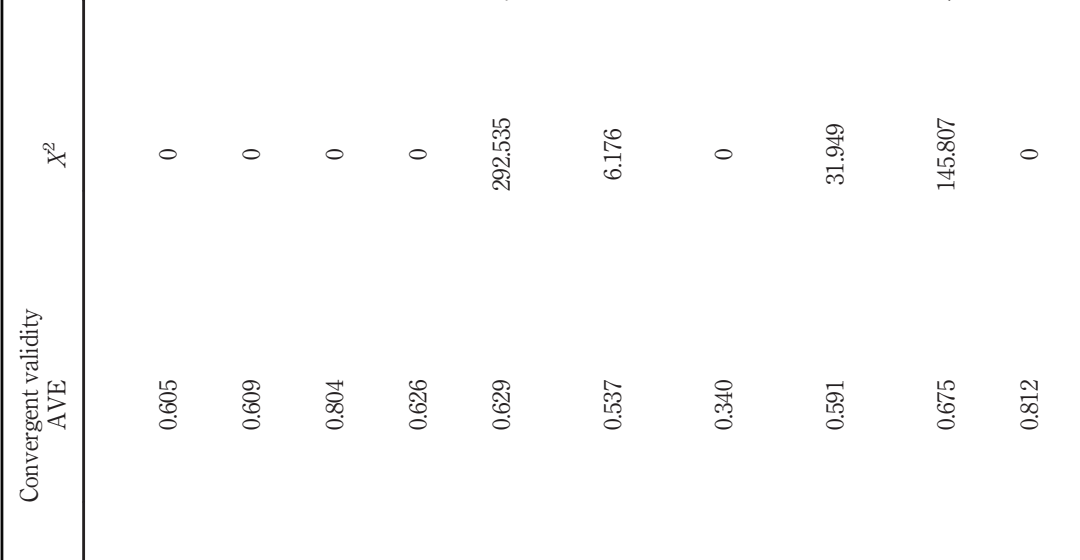

Table 3.

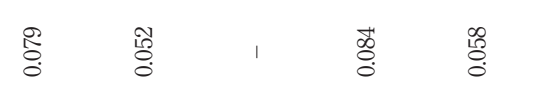

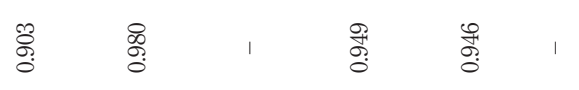

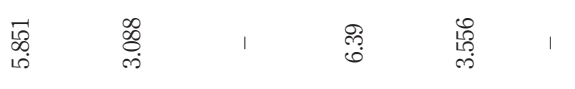

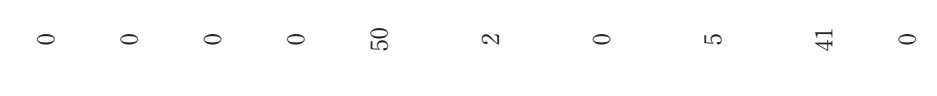

1

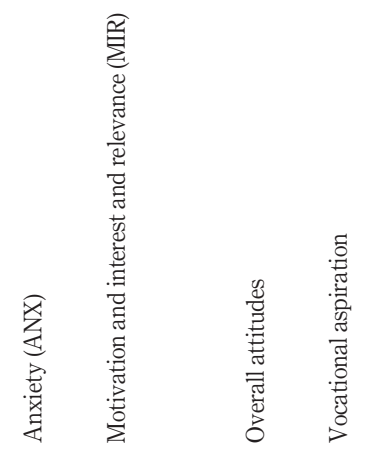




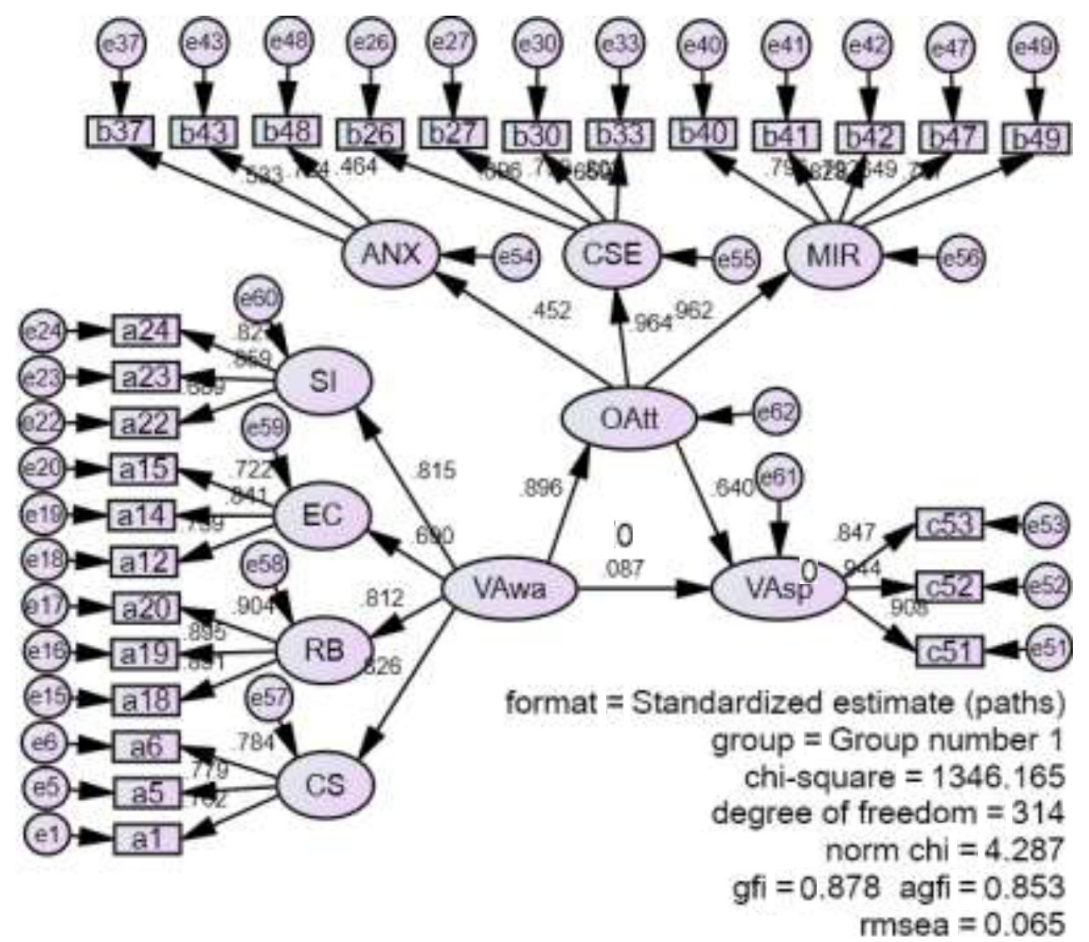

Figure 2 shows the SEM model of the vocational aspiration factors produced with the AMOS software, and Table 4 shows the results of the Bollen-Stine bootstrap $p$-correction. In Table 4, most of the GFI values are within the ideal ranges and the $P$ value being 0.000 , indicating that the null hypothesis, $\mathrm{HO}$ is rejected, and the alternative hypothesis, $\mathrm{Ha}$ is most likely true. However, some of the values fall outside of the ideal ranges, including $\chi^{2} / \mathrm{df}$ which is $4.287(>3)$, GFI $0.878(<0.9)$ and AGFI $0.853(<0.9)$. While the misfits are shown by the enlargement of the chi-square values and the violations of multivariate normality, considering that the number of samples (774) is much bigger than the suggested minimum of 200, it was decided to improve the model through Bollen-Stine $p$-value correction method (Kline, 2011).

\begin{tabular}{|c|c|c|c|c|c|c|c|c|c|c|}
\hline $\begin{array}{l}\text { Determination } \\
\text { index }\end{array}$ & $\chi^{2}$ & $\mathrm{df}$ & $\chi^{2} / \mathrm{df}$ & GFI & AGFI & NFI & $\begin{array}{l}\text { NNFI } \\
\text { (TLI) }\end{array}$ & CFI & SRMR & RMSEA \\
\hline Fit value & $\begin{array}{l}1,346.165 \\
p=0.000\end{array}$ & 314 & 4.287 & 0.878 & 0.853 & 0.902 & 0.914 & 0.923 & 0.0575 & 0.065 \\
\hline $\begin{array}{l}\text { Fit value with } \\
\text { Bollen-Stine } p \\
\text { correction }\end{array}$ & $\begin{array}{r}442.550 \\
p=0.999\end{array}$ & 314 & 1.41 & 0.97 & 0.96 & 0.97 & 0.99 & 0.99 & - & - \\
\hline Ideal value & $\begin{array}{c}\text { As small } \\
\text { as possible }\end{array}$ & $\begin{array}{c}\text { As large } \\
\text { as possible }\end{array}$ & $<3-5$ & $>0.9$ & $>0.9$ & $>0.9$ & $>0.9$ & $>0.9$ & $<0.05-0.08$ & $<0.05-0.08$ \\
\hline
\end{tabular}

\section{Vocational awareness and aspiration}

Figure 2.

SEM model of vocational aspiration Assessment of fit of the model: original and after BollenStine $p$ correction 
MABR

7,2
The third raw in Table 4 shows the fit values after Bollen-Stine bootstrap corrections, where the number of bootstrap samples was 1,000, and the average chi-square is 442.550, much smaller than 1,346.165, the chi-square acquired with maximum likelihood estimation. Other indices also improved to fit into the SEM standards, indicating a very good model fit to the data and the model is statistically significant.

\section{8}

\subsection{Mediation analysis}

Baron and Kenny (1986) proposed a four-step mediation test, and this test is adopted to verify a mediation effect on vocational aspiration from vocational awareness through overall attitudes, and to determine the strength of the mediation effect. The resulted values are listed in Figure 3: the models of mediation effect test.

Test 1: The effects of vocational awareness over vocational aspiration is confirmed to be positively significant, with a path coefficient of $0.657, t$-values of 14.525 and a threeasterisk $P$ value $(<0.001)$. $H 2$ is therefore confirmed.

Test 2: The effects of vocational awareness on overall attitudes is confirmed to be positively significant, with a path coefficient of $0.896, t$-values of 7.507 and a threeasterisk $P$ value $(<0.001)$.

Test 3: With both vocational awareness and overall attitudes included as direct factors for vocational aspiration, the effects of overall attitudes towards vocational aspiration remain highly significant, with a path coefficient of $0.650, t$-values of 4.933 and a three-asterisk $P$ value $(<001)$.

Test 4: With both vocational awareness and overall attitudes included as direct factors for vocational aspiration, the effects of vocational awareness towards vocational aspiration became substantially insignificant with a path coefficient of 0.087 , and $t$-values of 0.839 .

The results of Test 1,2, 3 and 4 confirm that with the addition of overall attitudes in the model, the effects of vocational awareness over vocational aspiration changed from significant to insignificant. However, the paths of vocational awareness to overall attitudes and of overall attitudes to vocational aspiration remain significant, indicating a strong mediation effect of overall attitudes on vocational awareness for vocational aspiration. Furthermore, the indirect path coefficient of vocational awareness over vocational aspiration is $0.573(0.896 \times 0.640)$, which is only 0.084 less than the direct path coefficient, 0.657 , indicating that the mediation effect, while partial, is comprehensive. Thus, $H 1, H 2$ and $H 4$ are supported. However, $H 3$ was not supported in this research.

Figure 3.

Models of mediation effect testing
Model 3

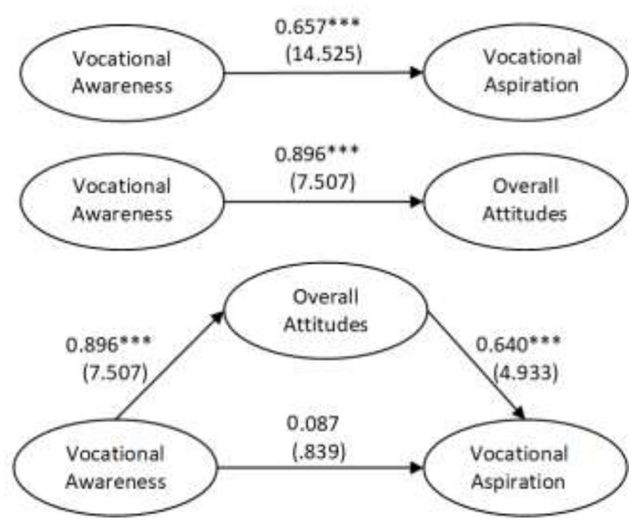




\section{Conclusions and discussion}

This research aims to examine the relationships between vocational awareness, overall attitudes of seafaring and vocational aspiration from a maritime student's perspective. Resulted indicated that students' vocational awareness had a positive influence on their overall attitudes of seafaring, whereas overall attitudes of seafaring was positively related to the students' vocational aspiration. Specifically, this study found that students' overall attitudes played a fully mediation effort in the relationship between vocational awareness and vocational aspiration. However, the direct influence of vocational awareness on vocational aspiration was not supported in this research due to the mediating role of overall attitudes of seafaring. The results confirm and support the findings from the literature review.

The confirmation of hypotheses and observed effects of the factors of vocational awareness and overall attitudes over vocational aspiration have strong implications on how to improve vocational aspiration of the students in seafaring courses.

This research confirmed that vocational awareness (CS, RB, EC and SI) can improve students' overall attitudes of seafaring. In addition, students' overall attitudes (MIR, CSE and ANX) can reinforce students' vocational aspiration of seafaring.

There are four groups: governments, schools (educators), shipping companies (the industry) and students, each plays a role in the status of the shipping industry and has capacity and power to influence the factors identified in this study of the vocational aspiration.

Governments can formulate policies to bring about favourable conditions for investments, to stimulate market demands for shipping services and therefore to improve remuneration, benefits and work conditions for the employees in the industry. Furthermore, to enhance vocational aspiration of students in seafaring courses, the governments can enhance counselling services for students and citizens to be better informed of RB, EC, MIR, etc. and to alleviate negative impressions (ANX) on seafaring careers.

Schools (universities, colleges and other institutes) are responsible for nurturing future employees and talents for the industries and are ideally positioned to impact on each student's career aspiration. To strength the CSE, SI, MIR and RB will increase students' vocational aspiration. Therefore, school educators should provide the best possible curriculum and environment for students to learn vocational knowledge and knowhow, including skills on problem-solving, planning and execution (CS), to enhance on students' MIR and CSE and to mitigate ANX related to school work and seafaring careers.

This study suggests that shipping companies could endeavour to provide rewarding, safe and enjoyable work and living environment for their employees with generous benefits included in seafarers' packages (Tsai and Liou, 2017; Rai, 2019). Furthermore, they can provide better living conditions on ships and take better care of corporate social responsibilities which are critical to retain seafarers (Osipow et al., 2000; Thai et al., 2013). These practices will enhance factors including $\mathrm{RB}$ and $\mathrm{EC}$ and help to attract the best talented and well-trained employees and to provide stability and profitability for the shipping industry (Jonathan, 1998; Spokane and Cruza-Guet, 2005).

Students on seafaring courses are the subjects of this study; they should focus on their learning and prepare themselves for the challenges ahead of their careers. A seafaring career can be extremely fulfilling and rewarding provided that they: 1) understand their personal traits of student's MIR, 2) build up their skill sets on decision-making, planning and execution, to enhance their CSE, 3) comprehend conditions on ships and communicate with family and friends and 4) nurture positive attitudes and mitigate anxiety.

When the factors identified in this study are enhanced, the levels of vocational awareness and overall attitudes will improve resulting in stronger interest for seafaring students to 
MABR

7,2

pursue seafaring careers (vocational aspiration). There will be more successful careers, better personal satisfaction and benefits for the industry and the economy.

In the process of the mediation effect analysis (Section 4.3), it was observed that students in shipping navigation courses with good academic performance do not necessarily have high vocational aspiration. This can be conjectured that students with higher grades tend to have more diverse aspiration and higher expectation and more options on work or further studies. Therefore, the schools should modify their recruitment policies to focus more on students with good vocational awareness and attitudes, rather than those with highest possible grades. This issue, of how to acquire most suitable students who will develop into capable seafarers and stay on the intended career path in the shipping industry, is a potential topic for future research.

\section{References}

Ajzen, I. (1991), "The theory of planned behavior, organizational behavior and human decision process", Organizational Behavior and Human Decision Processes, Vol. 50 No. 2, pp. 179-211.

Ajzen, I. (2001), "Nature and operation of attitudes", Annual Review of Psychology, Vol. 52 No. 1, pp. 27-58.

Baartman, L.K.J. (2018), "VET students' integration of knowledge engaged with in school-based and workplace-based learning environments in The Netherlands", Journal of Education and Work, Vol. 31 No. 2, pp. 204-217.

Baron, R.M. and Kenny, D.A. (1986), "The moderator-mediator variable distinction in social psychological research: conceptual, strategic, and statistical considerations", Journal of Personality and Social Psychology, Vol. 51 No. 6, pp. 1173-1182.

Bassot, B. (2019), "Action without action planning: the potential of the career thinking session in enabling transformational career learning and development", British Journal of Guidance and Counselling, Vol. 47No No. 5, pp. 545-555.

Bollen, K.A. and Long, J.S. (1993), Testing Structural Equation Models, Sage Publications.

Boxer, P., Goldstein, S.E., DeLorenzo, T., Savoy, S. and Mercado, I. (2011), "Educational aspirationexpectation discrepancies: relation to socioeconomic and academic risk-related factors", Journal of Adolescence, Vol. 34 No. 4, pp. 609-617.

Broad, J.H. (2016), "Vocational knowledge in motion: rethinking vocational knowledge through vocational teachers' professional development", Journal of Vocational Education and Training, Vol. 68 No. 2, pp. 143-160.

Burman, E. (2016), Deconstructing Developmental Psychology (3rd ed.), London: Routledge.

Bussing, A. (1999), "Can control at work and social support moderate psychological consequences of job insecurity? Results from a quasi-experimental study in the steel industry", European Journal of Work and Organizational Psychology, Vol. 8 No. 2, pp. 219-242.

Carotenuto, A., Molino, I., Fasanaro, A.M. and Amenta, F. (2012), "Psychological stress in seafarers: a review", International Maritime Health, Vol. 63, pp. 188-194.

Cherry, N. and Gear, R. (1987), "Young people's perceptions of their vocational guidance needs: II. Influences and interventions", British Journal of Guidance and Counselling, Vol. 15 No. 2, pp. 169-181.

Deci, E.L., Vallerand, R.J., Pelletier, L.G. and Ryan, R.M. (1991), "Motivation and education: the selfdetermination perspective", Educational Psychologist, Vol. 26 No. 3, pp. 325-346.

Enache, R.G. and Matei, R.S. (2017), "Study on self-awareness and vocational counselling of high school students", Agora Psycho-Pragmatica, Vol. 11 No. 1, pp. 57-64.

Ferrara, J., Rudrud, E., Wendlegass, P. and Markve, R.A. (1985), "Vocational awareness training and job preferences among mentally retarded adults", Vocational Guidance Quarterly, Vol. 33 No. 4, pp. 305-314. 
Ford, D.H. and Lerner, R.M. (1992), Developmental Systems Theory: An Integrative Approach, Sage Publications, Inc.

Fornell, C. and Larcker, D.F. (1981), "Evaluating structural equation models with unobservable variables and measurement error", Journal of Marketing Research, Vol. 18 No. 1, pp. 39-50.

Galotti, K.M. and Kozberg, S.F. (1987), “Older adolescents' thinking about academic/vocational and interpersonal commitment", Journal of Youth and Adolescence, Vol. 16 No. 4, pp. 313-330.

Helwig, A.A. (1984), "Increasing vocational self-awareness in high school students", The School Counselor, Vol. 32 No. 1, pp. 61-67.

Herr, E.L. and Cramer, S.H. (1988), Career Guidance and Counselling through the Life Span: Systematic Approaches (3rd ed.), Glenview, IL: Scott, Foresman.

Hidi, S. and Renninger, K.A. (2006), "The four-phase model of interest development", Educational Psychologist, Vol. 41 No. 2, pp. 111-127.

Holland, J.L. (1985), The Self-Directed Search Professional Manual, Odessa, FL: Psychological Assessment Resources.

Holland, J.L. (1997), Making Vocational Choices: A Theory of Vocational Personalities and Work Environments, (3rd ed.), Psychological Assessment Resources.

Hong, Z.R. (2010), "Effects of a collaborative science intervention on high achieving students' learning anxiety and attitudes toward science", International Journal of Science Education, Vol. 32 No. 15, pp. 1971-1988.

Hyland, T. (2019), "Embodied learning in vocational education and training", Journal of Vocational Education and Training, Vol. 71 No. 3, pp. 449-463.

Jonathan, M.H. (1998), "Increasing vocational awareness through an 'environmental impacts of business and industry' module", Journal of Geography in Higher Education, Vol. 22 No. 1, pp. 120-125.

Kind, P., Jones, K. and Barmby, P. (2007), "Developing attitudes towards science measures", International Journal of Science Education, Vol. 29 No. 7, pp. 871-893.

Kline, R.B. (2011), Principle and Practice of Structural Equation Modelling (3rd ed.), Guilford, New York, NY.

Lent, R.W., Brown, S.D. and Hackett, G. (1994), "Toward a unifying social cognitive theory of career and academic interest, choice, and performance", Journal of Vocational Behavior, Vol. 45 No. 1, pp. 79-122.

McGroarty, M. (1985), "Language proficiency, technical skill, and vocational awareness: instructor competencies for bilingual vocational training", NABE Journal, Vol. 9 No. 2, pp. 25-40.

Mudhovozi, P. and Chireshe, R. (2012), "Socio-demographic factors influencing career decision- making among undergraduate psychology students in South Africa", Journal of Social Sciences, Vol. 31 No. 2, pp. 167-176.

Ocean Affairs Council (2006), Ocean Policy White Paper 2006, Taipei: Executive Yuan Examination Conference. , available at: www.govbooks.com.tw

Osborne, J., Simon, S. and Collins, S. (2003), "Attitudes towards science: a review of the literature and its implications”, International Journal of Science Education, Vol. 25 No. 9, pp. 1049-1079.

Osipow, G.I., Krausz, S.H. and Saka, N. (2000), "Validity of the career decision-making difficulties questionnaire: counselee versus career counsellor perceptions", Journal of Vocational Behavior, Vol. 56 No. 1, pp. 99-113.

Parkes, K.R., Carnell, S.C. and Farmer, E.L. (2005), "Living two lives. Perceptions, attitudes and experiences of spouses of UK offshore workers", Community, Work and Family, Vol. 8 No. 4, pp. 413-437.

Pintrich, P.R. and Schunk, D.H. (2002), Motivation in Education: Theory, Research and Applications, Upper Saddle River: Merrill Prentice Hall. 
MABR

7,2

Potvin, P. and Hasni, A. (2014), "Interest, motivation and attitude towards science and technology at K12 levels: a systematic review of 12 years of educational research", Studies in Science Education, Vol. 50 No. 1, pp. 85-129.

Rai, A. (2019), "An application of the instrumental-symbolic framework in maritime industry: a study on employer branding among seafarers", Management Research Review, Vol. 43 No. 3, pp. 270-292.

Ryan, R.M. and Deci, E.I. (2000), "Self-determination theory and the facilitation of intrinsic motivation, social development, and well-being", American Psychologist, Vol. 55 No. 1, pp. 68-78.

Savelsbergh, E.R., Prins, G.T., Rietbergen, C., Fechner, S., Vaessen, B.E., Draijer, J.M. and Bakker, A. (2016), "Effects of innovative science and mathematics teaching on student attitudes and achievement: a meta-analytic study”, Educational Research Review, Vol. 19, pp. 158-172.

Schommer, M. (1990), "Effects of beliefs about the nature of knowledge on comprehension", Journal of Educational Psychology, Vol. 82 No. 3, pp. 498-504.

Sheldrake, A., Mujtaba, T. and Reiss, M.J. (2017), "Science teaching and students' attitudes and aspirations: the importance of conveying the applications and relevance of science", International Journal of Educational Research, Vol. 85, pp. 167-183.

Shumba, A. and Naong, M. (2012), "Factors influencing students' career choice and aspirations in South Africa”, Journal of Social Sciences, Vol. 33 No. 2, pp. 169-178.

Slišković, A. and Juranko, A. (2019), "Dual life of seafarers' families: descriptive study of perspectives of seafarers' partners", Community, Work and Family, Vol. 22 No. 5, pp. 629-646.

Slišković, A. and Penezić, Z. (2015b), "Descriptive study of job satisfaction and job dissatisfaction in a sample of Croatian seafarers", International Maritime Health, Vol. 66 No. 2, pp. 97-105.

Spokane, A.R. and Cruza-Guet, M.C. (2005), "Holland's theory of vocational personalities in work environments", in Brown, S.D. and Lent, R.W. (Eds), Career Development and Counselling: Putting Theory and Research to Work, NJ: Wiley pp. 24-38.

Super, D.E. (1981), "Approaches to occupational choice and career development”, in Watts, A.G., Super, D.E. and Kidd, J.M. (Eds), Career Development in, Hobsons, Britain, Cambridge, England.

Super, D.E. (1990), "A life-span, life-space approach, career choice and development”, in Brown, D. and Brooks, L. (Eds), Career Choice and Development: Applying Contemporary Theories to Practice, Jossey-Bass, San Francisco.

Super, D.E. (1994), "A life span, life space perspective on convergence”, in Savikas, M.L. and Lent, R.W. (Eds), Convergence in Career Development Theories: Implications for Science and Practice pp. 63-74, CPP Books.

Thai, V.V., Balasubramanyam, L., Yeoh, K.K.L. and Norsofiana, S. (2013), "Revisiting the seafarer shortage problem: the case of Singapore”, Maritime Policy and Management, Vol. 40 No. 1, pp. 80-94.

Tsai, C.L. and Liou, Y.W. (2017), "Determinants of work performance of seafarers", Maritime Business Review, Vol. 2 No. 1, pp. 36-51.

Tuan, H.L., Chin, C.C. and Shieh, S.H. (2005), "The development of a questionnaire to measure students' motivation towards science learning", International Journal of Science Education, Vol. 27 No. 6, pp. 639-654.

Virtanen, A., Tynjälä, P. and Eteläpelto, A. (2014), "Factors promoting vocational students' learning at work: study on student experiences", Journal of Education and Work, Vol. 27 No. 1, pp. 43-70.

Watt, H.M.G. and Richardson, P.W. (2007), "Motivational factors influencing teaching as a career choice: development and validation of the FIT-choice scale", The Journal of Experimental Education, Vol. 75 No. 3, pp. 167-202. 
Watt, H.M.G. and Richardson, P.W. (2012), "An introduction to teaching motivations in different countries: comparisons using the FIT-Choice scale", Asia-Pacific Journal of Teacher Education, Vol. 40 No. 3, pp. 185-197.

Westlander, G. (1994), "Training of psychologists in occupational health work: ten years of course development - experience and future perspectives", European Work and Organizational Psychologist, Vol. 4 No. 2, pp. 189-202.

Wise, R., Charner, I. and Randour, M.L. (1976), “A conceptual framework for career awareness in career decision-making", The Counseling Psychologist, Vol. 6 No. 3, pp. 47-53.

Wong, C.P. (2010), "A study of development of yacht crew labor market in ROC", Journal of Marine Technology, No. 3, pp. 63-74.

Wong, C.P. (2012), "A study of leadership qualities in vocational education of master mariner", Journal of Asian Vocational Education and Training, Vol. 5 No. 1, pp. 59-70.

Wu, Y.L. and Lou, S.J. (2010), "The study on the major choice, occupational knowledge, and teaching commitment of child care department students in colleges of science and technology", Technology and Vocational Education, Vol. 1 No. 2, pp. 1-17.

Yu, M.N., Chao, P.C. and Cheng, C.C. (2010), "Investigating the factors on mathematics career-choice intentions with the social cognitive career theory", Journal of Research in Education Sciences, Vol. 55 No. 3, pp. 177-201.

\title{
Further reading
}

Bollen, K.A. (1989), Structural Equations with Latent Variables, Wiley, New York, NY.

Hair, J.F., Jr, Anderson, R.E., Tatham, R.L. and Black, W.C. (2009), Multivariate Data Analysis (7th ed.), Prentice Hall, Englewood Cliffs, NJ.

Kirk, R.E. (2013), Experimental Design: Procedures for the Behavioral Sciences (4th ed.), CA: Brooks/ Code Publishing Company.

Murphy, K.R., Myors, B. and Wolach, A. (2014), Statistical Power Analysis: A Simple and General Model for Traditional and Modern Hypothesis Tests (4th ed.), Lawrence Erlbaum Associates, Mahwah, NJ.

Warner, R.M. (2012), Applied Statistics: From Bivariate through Multivariate Techniques (2nd ed.), LA: Sage.

\begin{abstract}
About the author
Chun Pong Wong (黃振邦) Prof Wong Chun-Pong received a PhD from National Kaohsiung Normal University in 2012 and acquired an MBA degree from National Sun Yat-sen University. He is an experienced Marine Master on cargo ships; his specialty includes ship handling and building and marketing, shipbuilding industry, ship handling, marine cargo operation, ship stability, etc. Currently, he serves in the Department of Shipping and Technology at National Kaohsiung University of Science and Technology, Taiwan. Chun Pong Wong can be contacted at: cp@nkust.edu.tw
\end{abstract}


MABR

7,2

144

\section{Appendix}

$\underline{\text { The Questionnaire for Vocational Awareness and Aspiration Study }}$

(7).

With 7 options for most questions, the intensity of expression ranges from strongly disagree (1) to strongly agree

Part 1. Questions on Vocational Awareness

(Competence)

a1 I understand the contents of the subjects relating to general study in the school.

a2 I understand the contents of the qualification examination for a license for shipping officers

a3 I understand the contents of the internship on ships

a4 I understand vocational requirements for the shipping officers on ships

(Job Security)

a8 I know the demand and trend for shipping officers in current job markets

a9 I know the career options for non-shipping jobs in the job market

a10 I understand the limitation of non-seafaring jobs available after a seafaring career.

a18 I know the type of career I want to pursue.

a19 I understand the compatibility between my interest and a seafaring career.

a20 I understand the progress and expectation on a seafaring career.

(Environment and Conditions)

a11 I understand the living environment and conditions of seafaring jobs.

a12 I understand the risks and difficulties of working on ships.

a13 I understand the fixed terms of contracts for seafaring jobs.

a14 I know that seafarers travel to and live in everywhere the ships go to.

a15 I know that language skills is a prerequisite for seafaring jobs.

(Rewards and Benefits)

a5 I understand general salaries and rewards for seafaring jobs

a6 I understand general benefits and supports for seafaring jobs

a7 I understand general differences in remuneration packages among seafaring jobs and non-seafaring jobs

a16 I understand what I need to learn from my seafaring study.

a17 I know my expectations from a seafaring career.

(Social Influences)

a21 My family support my choice of a seafaring career.

a22 My friends and peers support my choice of a seafaring career.

a23 The school environment is helpful in my choice of a seafaring career.

a24. Conventional concepts on seafaring careers affects my decision to pursue a seafaring career.

Part 2. Questions on overall attitude

(Motivation)

b28 It will be easier to find a seafaring job if I do well in the seafaring and relevant studies.

b40 My skills and capability will grow if I do well in the seafaring and relevant studies.

b46 My family and friends will appreciate my effort if I do well in the seafaring and relevant studies.

(Interest)

b30 I am interested on seafaring and relevant studies.

b36 The on-ship internship program makes me interested on a seafaring career

b42 The atmosphere and environment in the school makes me interested on a seafaring career.

b47 The aspects of travelling overseas makes me interested on a seafaring career.

b50 The types of work in seafaring jobs makes me interested on a seafaring career.

(Relevance)

b29 Having good seafaring knowledge and skills can enhance my self-assurance.

b34 Doing well in the seafaring and relevant studies helps in finding better paid jobs.

b35 Having good seafaring knowledge and skills helps in winning recognition from others.

b41 Having good seafaring knowledge and skills helps in winning recognition from friends and peers.

(Self-efficacy)

b27 I study hard on seafaring and relevant studies.

b33 I prepare for the contents of the classes on seafaring subjects.

b39 I study the contents of the seafaring subjects after the classes.

b45 I work hard to pick up skills in the practicum classes.

b49 I participate actively in activities relating to seafaring studies and relevant topics.

(Confidence)

b26 I am confident that I can do well in the seafaring and relevant studies.

b32 I am confident that I can pass the examinations and vocational trainings in the school.

b38 I am confident that I will be able to pass the examinations for the seafaring licence.

b44 I am confident that I will be able to do the seafaring jobs well.

(Career anxiety)

b37 I think dealing with fellow seafarers from different countries on ship is difficult.

b43 I think there is a degree of danger and risk on seafaring jobs.

b48 I know that I will be away from family and friends when I work on ships.

Part 3. Questions on Vocational Aspiration

c51 I will pursue a seafaring career when I graduate.

c52 A seafaring career matches my career plan.

c53 I m willing to accept the difficulties and risks involved in a seafaring career.

Part 4. Questions on responder's details and backgrounds

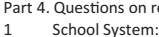

2 Gender: $\square$ Male, $\square$ Female.

3 Internship Time: $\square 0^{\sim} 3$ months, $\square$ 4 7 months, $\square 8^{\sim} 11$ months, $\square 1$ year and above

4 Academic performance in percentage ranks from best ( $\leq 10 \%)$ to worst $(100 \%)$ :

口Top: $\leq 10 \%$, $\square$ Good: $11 \sim 30 \%$, ฉAverage: $31 \sim 60 \%$, $\square$ Below Average: $\geq 61 \%$.

5 Household Income: $₫$ Very Good, $\square$ Good, $\square$ Average, $\square$ Poor, $₫$ Very Poor.

6 Seafaring family and relatives: $\square$ Yes, $\square$ No. 